\title{
THE STRENGTH OF THE MENISCI OF THE KNEE AS IT RELATES TO THEIR FINE STRUCTURE
}

\author{
Peter G. Bullough, Luis Munuera, Joseph Murphy and Allan M. Weinstein, \\ New York, L'Nited States of America
}

From the Department of Physical and Engineering Metallurgy, Polytechnic Institute of Brooklyn, New York, and the Hospital for Special Surgery-Philip D. Wilson Research Foundation, Affiliated with the New York HospitalCornell University Medical College, and the Department of Pathology, Cornell University Medical College, New York

Studies on the elbow and hip joint (Goodfellow and Bullough 1967, 1968) have shown that cartilage softening and fibrillation first occur in the unloaded or only occasionally loaded areas of those joints. Bennett, Waine and Bauer (1942) found that two of the earliest and most constantly affected areas showing such changes in the knee were the exposed portions of the tibial plateau-that is, those areas not covered by the merrisci (Fig. 1).

The studies of Fairbank (1948) as well as our own (to be reported later) have suggested that a significant proportion of the load transferred across the knee joint may be carried through the menisci.

As part of a wider study of the load-carrying characteristics of the knee joint we have studied the fibre structure of the meniscus and tested the strength of its composite structure in tension as it relates to fibre orientation.

\section{MATERIALS AND METHODS}

Specimens of intact menisci were obtained at necropsy or from amputated limbs. The subjects were of various ages and, so far as we were able to discover, had never had symptoms referable to the knee.

As has been demonstrated previously, the distribution of collagen fibres in articular cartilage can be displayed by making pinpricks in the surface which will tend to crack according to the direction of the fibres. Collagen fibres can be visualised by polarised light microscopy of orientated sections (Bullough and Goodfellow 1968). Using a similar procedure, we have looked at the collagen orientation in the menisci of the knee joint.

The tensile strength of the meniscal tissue was tested by cutting thin sections on a cryostat

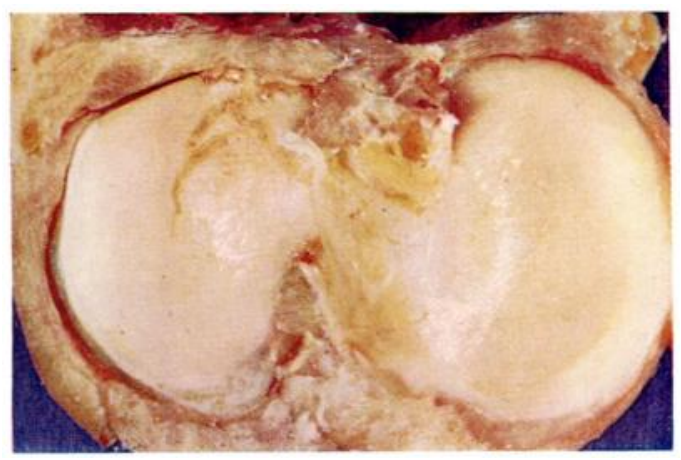

Fig. 1

Photograph of the tibial plateau from a 45-year-old woman after removal of the menisci. Note the degenerative changes on the exposed parts of the cartilage, that is the parts not covered by the menisci. The changes are typically more severe on the lateral condyle. between 9 and $20 \mu$ in thickness. The orientation of the fibres in each specimen was determined by polarised light microscopy.

A preliminary test revealed that there was no significant difference in strength between fresh tissue and tissue fixed in formalin; all the reported tests were performed on formalin-fixed tissue as this was more convenient.

A specially designed tensometer was used for the tensile tests (Fig. 2). The load was monitored with a Mosely Model 7000A X-Y recorder. A more detailed description of the testing apparatus is given elsewhere (Weinstein, D’Antonio and Ferraglio 1968). Throughout the entire test a liquid film of 
isotonic saline was maintained around the specimen to prevent dehydration. A test was carried out on the liquid film with no sample in place and it was found that loads less than $1 \times 10^{-3}$ kilograms were sufficient to cause the film to break. It is therefore reasonable to exclude the possibility of the liquid film adding to the observed load-carrying capacity of the actual specimens.

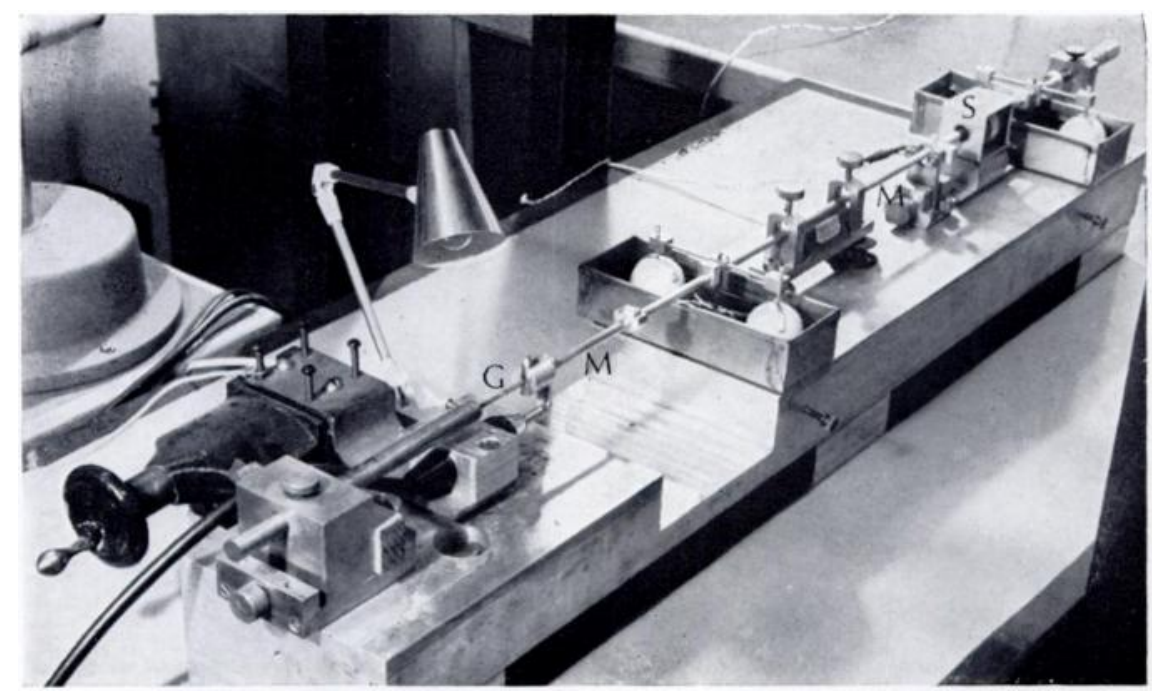

FiG. 2

Tensometer used for testing samples of meniscal tissue. The specimens were mounted across the grips $(G)$ and were held in place mechanically. The load was applied by passing a known current through the solenoid (S), drawing the permanently magnetised movable arm (M) through its orifice.

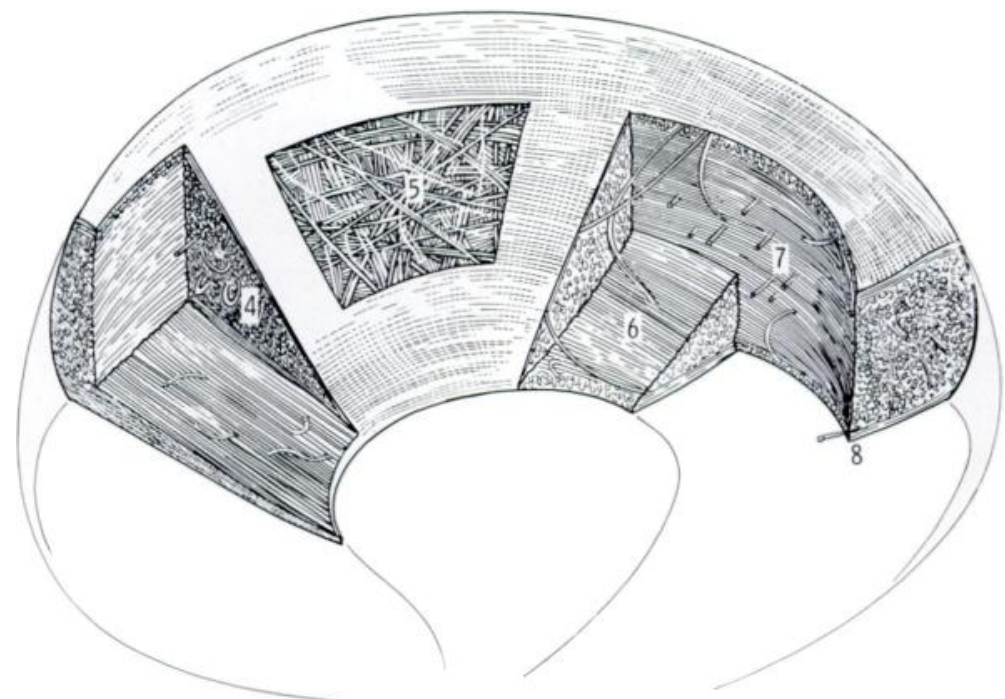

Fig. 3

Reconstruction of the fibre pattern of the meniscus. The numbers on the figure indicate the planes of section and the location of Figures 4 to 8.

The width of each sample was determined by measuring it under a binocular microscope with a filar eyepiece. Measurements of thickness were carried out with a Peacock number 25 thickness gauge. It was found that the calculated breaking stresses were not dependent upon the physical dimensions of the specimen.

VOL. 52 B, No. 3, AUGUST 1970 


\section{RESULTS}

From studies of many sections cut in different planes we have derived a three-dimensional model of the collagen distribution (Fig. 3), which is similar for both the lateral and medial meniscus. Figures 4 to 8 are photomicrographs, illuminated with polarised light, in different planes of section as shown in Figure 3.

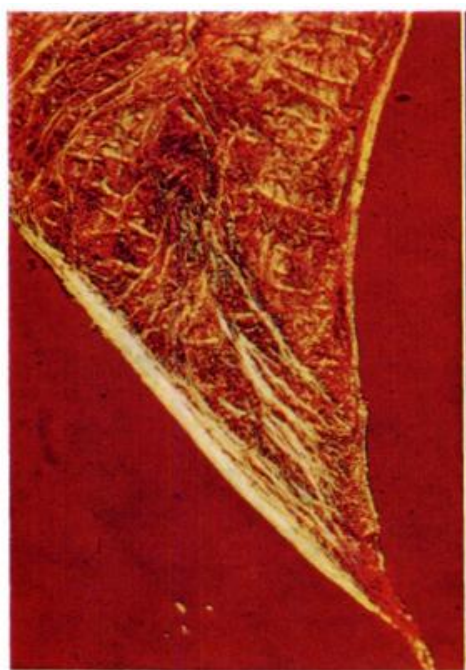

Fig. 4

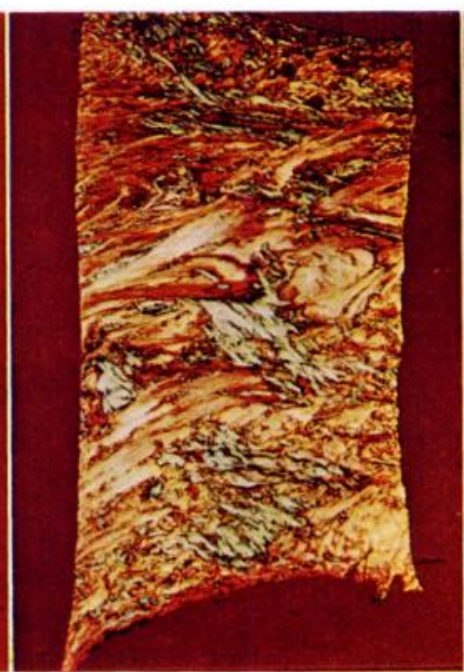

Fig. 5

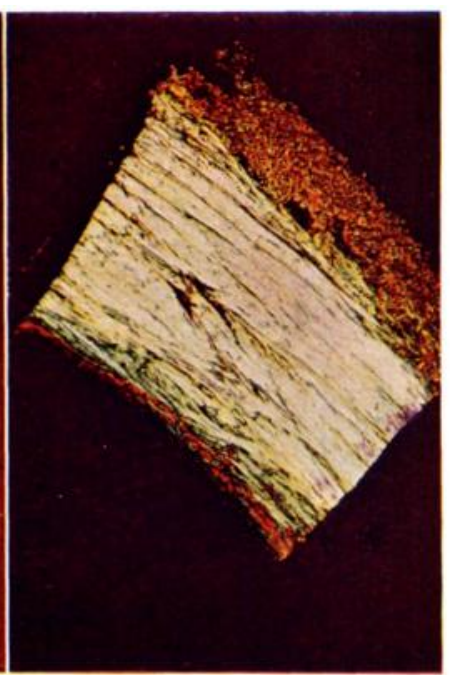

Fig. 6

Figure 4-Photomicrograph of a section through the meniscus. Note the more prominent radial fibres on the tibial surface of the meniscus at bottom left. (Polarised light.) Figure 5-Photomicrograph of a section tangential to the femoral surface of the meniscus. Note the woven arrangement of the collagen bundles. (Polarised light.) Figure 6-Photomicrograph of a section taken through the centre of the meniscus to include both the inner and outer edges. The capsular attachment of the meniscus is seen at top right. Note the well orientated circumferential fibres. (Polarised light.)

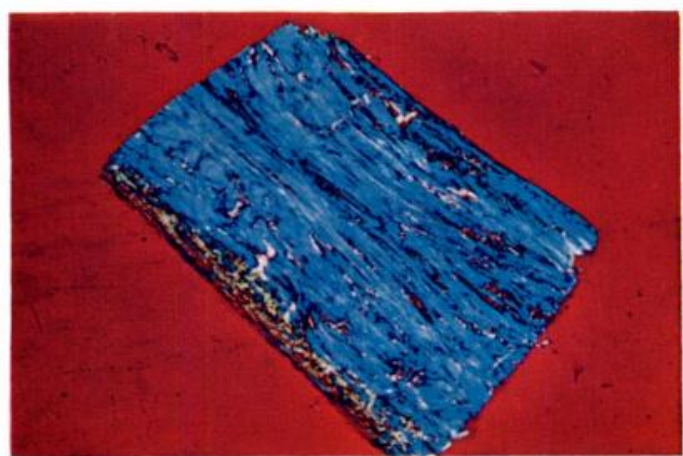

Fig. 7

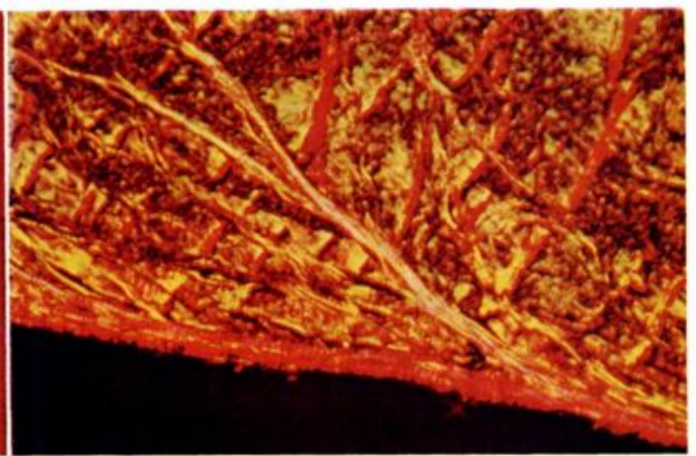

Fig. 8

Figure 7-Photomicrograph of a section taken through the thickness of the meniscus and parallel to its edge. Note more cross fibres (radial fibres) on the tibial surface, lower left. (Polarised light.) Figure 8-Photomicrograph (high power) to show collagen bundles from the radially disposed fibres on the tibial surface curling up into the substance of the meniscus. (Polarised light.)

As will be appreciated, the principal orientation of the collagen fibres is circumferential. But there are radially disposed fibres in the mid-zone of the meniscus and also on the exposed surfaces, particularly the tibial surface. Some of these radially disposed fibres, as shown in Figure 3, curl and change direction to become perpendicular to the surface.

The variations in tensile strength-that is, the maximal and minimal strength-within each group are shown in Tables I and II. These variations may be accounted for by subtle changes 
TABLE I

Observations: Lateral Meniscus (Fourteen Specimens)

\begin{tabular}{|c|c|c|c|c|c|c|c|c|}
\hline \multirow{2}{*}{$\begin{array}{c}\text { Specimen } \\
\text { number }\end{array}$} & \multirow[b]{2}{*}{ Age } & \multirow{2}{*}{ Sex } & \multirow{2}{*}{$\begin{array}{l}\text { Adjacent } \\
\text { bone } \\
\text { surface }\end{array}$} & \multirow{2}{*}{$\begin{array}{l}\text { Location of } \\
\text { specimen in } \\
\text { meniscus }\end{array}$} & \multirow{2}{*}{$\begin{array}{l}\text { Principal orientation } \\
\text { of the fibres in } \\
\text { specimen in relation } \\
\text { to the tensile axis }\end{array}$} & \multicolumn{3}{|c|}{ Tensile strength } \\
\hline & & & & & & $\underset{\left.\left(\mathrm{kg} . / \mathrm{cm}_{.}\right)^{2}\right)}{\text { Maximum }}$ & $\underset{\left(\mathrm{kg} . / \mathrm{cm} .{ }^{2}\right)}{\operatorname{Minimum}}$ & $\underset{\left(\mathrm{kg} . / \mathrm{cm} .^{2}\right)}{\text { Mean }}$ \\
\hline 1 & 14 & Male & Femoral & Central & $\begin{array}{l}\text { Perpendicular with } \\
\text { many cross fibres }\end{array}$ & $9 \cdot 70$ & $6 \cdot 12$ & $7 \cdot 73$ \\
\hline 2 & 14 & Male & Femoral & Central & $\begin{array}{l}\text { Oblique (approxi- } \\
\text { mately } 30 \text { degrees) } \\
\text { with somecrossfibres }\end{array}$ & $20 \cdot 4$ & $12 \cdot 02$ & $14 \cdot 62$ \\
\hline 3 & 29 & Male & Tibial & Anterior horn & $\begin{array}{l}\text { Perpendicular with } \\
\text { many cross fibres }\end{array}$ & $11 \cdot 53$ & $8 \cdot 79$ & 9.98 \\
\hline 4 & 29 & Male & Tibial & Anterior horn & $\begin{array}{l}\text { Mainly parallel with } \\
\text { some cross fibres }\end{array}$ & $26 \cdot 71$ & $15 \cdot 82$ & $19 \cdot 68$ \\
\hline 5 & 31 & Male & Femoral & Central & Perpendicular & $10 \cdot 55$ & $9 \cdot 70$ & $10 \cdot 12$ \\
\hline 6 & 31 & Male & Femoral & Central & Parallel & $73 \cdot 11$ & $55 \cdot 19$ & $64 \cdot 32$ \\
\hline 7 & 36 & Female & Tibial & Posterior horn & Perpendicular & $6 \cdot 82$ & $4 \cdot 21$ & $5 \cdot 48$ \\
\hline 8 & 36 & Female & Tibial & Posterior horn & Parallel & $79 \cdot 79$ & $62 \cdot 22$ & 70.03 \\
\hline 9 & 40 & Male & Tibial & Anterior horn & Perpendicular & $12 \cdot 51$ & $6 \cdot 82$ & $9 \cdot 63$ \\
\hline 10 & 40 & Male & Tibial & Anterior horn & Parallel & $125 \cdot 13$ & $75 \cdot 22$ & $104 \cdot 04$ \\
\hline 11 & 52 & Male & Tibial & Anterior horn & Perpendicular & $8 \cdot 86$ & 6.04 & $7 \cdot 45$ \\
\hline 12 & 52 & Male & Tibial & Anterior horn & Parallel & $169 \cdot 42$ & $105 \cdot 45$ & $127 \cdot 24$ \\
\hline 13 & 58 & Female & Tibial & Anterior horn & Perpendicular & $6 \cdot 19$ & $5 \cdot 27$ & 5.69 \\
\hline 14 & 58 & Female & Tibial & Anterior horn & Parallel & $85 \cdot 77$ & $71 \cdot 00$ & $77 \cdot 75$ \\
\hline
\end{tabular}

in fibre direction in consecutive sections. For example, in specimens 29 and 30 (Table II) a marked change in strength was related to a marked change in fibre orientation observed microscopically.

The results are displayed graphically in Figures 9 and 10, where each bar on the graph represents the maximal strength observed in ten to twelve separate tests. The maximal strength has been plotted on the assumption that these specimens contained the least number of structural imperfections. As would be expected, the strength of the tissue is highly dependent upon the relative orientation of the fibres to the tensile axis. It will be seen from the bar graph that in the specimens with fibres orientated perpendicular to the tensile axis, cross fibres make little difference to the ultimate tensile strength; cross fibres in the specimens with parallel fibres can make a very significant difference to the strength.

\section{DISCUSSION}

The shape and attachments of the menisci are such that under normal loading conditions tension will be generated in them. Most of the collagen fibres in the meniscus are arranged circumferentially to withstand the tension. The radially disposed fibres probably act as tie fibres to resist longitudinal splitting of the meniscus.

Generally it may be said that there was little variation in the strength of the specimens in which the fibres were perpendicularly orientated compared with those in which the fibres were parallel to the tensile axis. It may be reasonably assumed that in the former specimens the strength was most dependent on the non-fibrillar matrix.

Vol. 52 B, NO. 3, AUGUST 1970 
TABLE II

Observations: Medial Meniscus (Eighteen Specimens)

\begin{tabular}{|c|c|c|c|c|c|c|c|c|}
\hline \multirow{2}{*}{$\begin{array}{c}\text { Specimen } \\
\text { number }\end{array}$} & \multirow{2}{*}{$\begin{array}{c}\text { Age } \\
\text { (years) }\end{array}$} & \multirow[b]{2}{*}{ Sex } & \multirow{2}{*}{$\begin{array}{l}\text { Adjacent } \\
\text { bone } \\
\text { surface }\end{array}$} & \multirow{2}{*}{$\begin{array}{l}\text { Location of } \\
\text { specimen in } \\
\text { meniscus }\end{array}$} & \multirow{2}{*}{$\begin{array}{l}\text { Principal orientation } \\
\text { of the fibres in } \\
\text { specimen in relation } \\
\text { to the tensile axis }\end{array}$} & \multicolumn{3}{|c|}{ Tensile strength } \\
\hline & & & & & & $\underset{\left(\mathrm{kg} . / \mathrm{cm} .{ }^{2}\right)}{\operatorname{Maximum}}$ & $\begin{array}{l}\text { Minimum } \\
\left(\mathrm{kg} . / \mathrm{cm} .{ }^{2}\right)\end{array}$ & $\begin{array}{c}\text { Mean } \\
\left(\mathrm{kg} \cdot / \mathrm{cm} .^{2}\right)\end{array}$ \\
\hline 15 & 15 & Female & Femoral & Posterior horn & Perpendicular & $10 \cdot 97$ & $7 \cdot 03$ & $9 \cdot 00$ \\
\hline 16 & 15 & Female & Femoral & Posterior horn & $\begin{array}{l}\text { Parallel with occa- } \\
\text { sional cross fibres }\end{array}$ & $38 \cdot 67$ & $31 \cdot 64$ & $35 \cdot 15$ \\
\hline 17 & 21 & Male & Tibial & Posterior horn & Perpendicular & $28 \cdot 19$ & $23 \cdot 69$ & $25 \cdot 58$ \\
\hline 18 & 21 & Male & Tibial & Posterior horn & Parallel & $102 \cdot 64$ & $70 \cdot 30$ & $84 \cdot 36$ \\
\hline 19 & 29 & Male & Femoral & Posterior horn & Almost perpendicular & $10 \cdot 83$ & $7 \cdot 24$ & $8 \cdot 58$ \\
\hline 20 & 29 & Male & Femoral & Posterior horn & Oblique & $68 \cdot 89$ & 53.08 & $60 \cdot 81$ \\
\hline 21 & 32 & Male & Femoral & Posterior horn & Perpendicular & $5 \cdot 41$ & $4 \cdot 57$ & $5 \cdot 13$ \\
\hline 22 & 32 & Male & Femoral & Posterior horn & Slightly oblique & $34 \cdot 59$ & $28 \cdot 82$ & $30 \cdot 37$ \\
\hline 23 & 40 & Male & Tibial & Posterior horn & $\begin{array}{l}\text { Perpendicular and } \\
\text { cross fibres }\end{array}$ & $20 \cdot 95$ & $16 \cdot 38$ & $18 \cdot 00$ \\
\hline 24 & 40 & Male & Tibial & Posterior horn & $\begin{array}{l}\text { Oblique with } \\
\text { cross fibres }\end{array}$ & $104 \cdot 04$ & $90 \cdot 69$ & 94.91 \\
\hline 25 & 42 & Male & Tibial & Posterior horn & $\begin{array}{l}\text { Perpendicular with } \\
\text { cross fibres }\end{array}$ & $9 \cdot 35$ & $7 \cdot 73$ & $8 \cdot 78$ \\
\hline 26 & 42 & Male & Tibial & Posterior horn & $\begin{array}{l}\text { Oblique with } \\
\text { cross fibres }\end{array}$ & $12 \cdot 30$ & $8 \cdot 72$ & $10 \cdot 83$ \\
\hline 27 & 52 & Male & Tibial & Central & $\begin{array}{l}\text { Oblique with } \\
\text { cross fibres }\end{array}$ & $52 \cdot 02$ & $30 \cdot 44$ & $39 \cdot 72$ \\
\hline 28 & 52 & Male & Tibial & Central & $\begin{array}{l}\text { Oblique with } \\
\text { cross fibres }\end{array}$ & $78 \cdot 03$ & $63 \cdot 62$ & $73 \cdot 11$ \\
\hline 29 & 53 & Male & Femoral & Central & Perpendicular & $12 \cdot 79$ & $4 \cdot 78$ & 6.96 \\
\hline 30 & 53 & Male & Femoral & Central & $\begin{array}{l}\text { Parallel with } \\
\text { some oblique }\end{array}$ & $47 \cdot 45$ & $28 \cdot 47$ & $34 \cdot 24$ \\
\hline 31 & 60 & Female & Femoral & Central & Perpendicular & $13 \cdot 43$ & $8 \cdot 65$ & $10 \cdot 33$ \\
\hline 32 & 60 & Female & Femoral & Central & $\begin{array}{l}\text { Oblique with } \\
\text { some cross fibres }\end{array}$ & $31 \cdot 28$ & $26 \cdot 85$ & $28 \cdot 97$ \\
\hline
\end{tabular}

It is interesting to observe the apparent increase in the tensile strength of the tissue of the lateral meniscus with increasing age. In the fourteen-year-old boy and the twenty-nineyear-old man the strength was low because of the existence of oblique and cross fibres. Specimens from the thirty-six-year-old woman and the fifty-eight-year-old woman were weaker than would be expected from the general trend, and this may be sex-determined. However, the specimen from the fifty-eight-year-old woman was stronger than that from the thirty-sixyear-old woman, which supports the view that tensile strength increases with age. This increase in strength may be accounted for by the increase in cross-linking of the collagen which is known to occur with advancing age (Schubert and Hamerman 1968).

The greatest tensile strength of the meniscus reported here is in the same order of magnitude as the strength found by Kempson, Freeman and Swanson (1968) for articular cartilage, which we have confirmed by independent tests on the articular cartilage of the femoral condyle. This fact tends to support the view that the menisci have a load-bearing function, for it might 
LATERAL MENISCUS

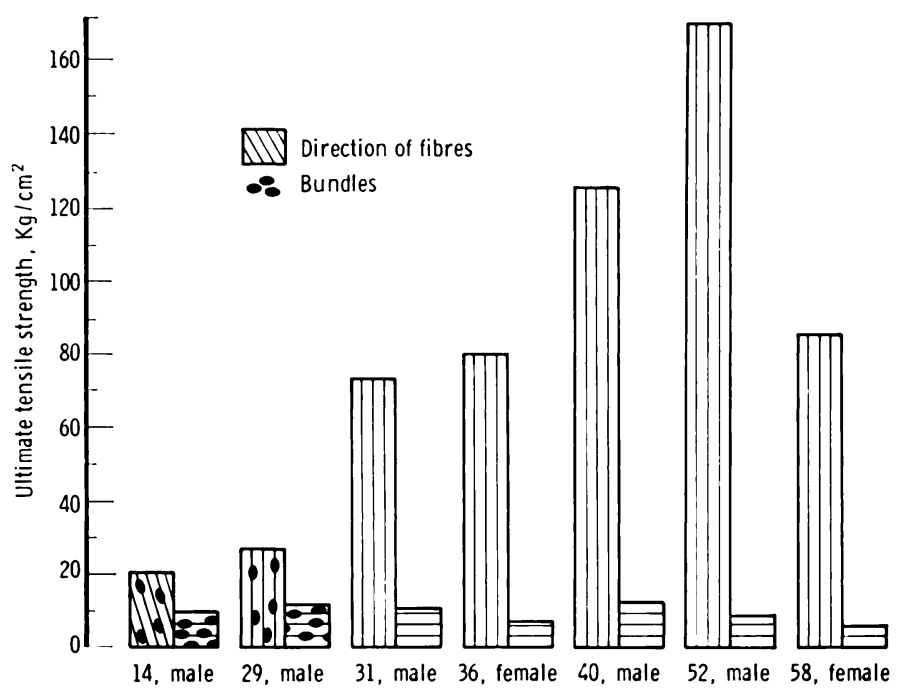

FIG. 9

Bar graph of the ultimate tensile strength of the tissue of the lateral meniscus related to the orientation of the collagen fibres in kilograms/ square centimetre. Each bar represents one specimen with the maximal tensile strength as described in Table I. Each group of two bars was taken from the same patient whose age and sex are given below.

MEDIAL MENISCUS

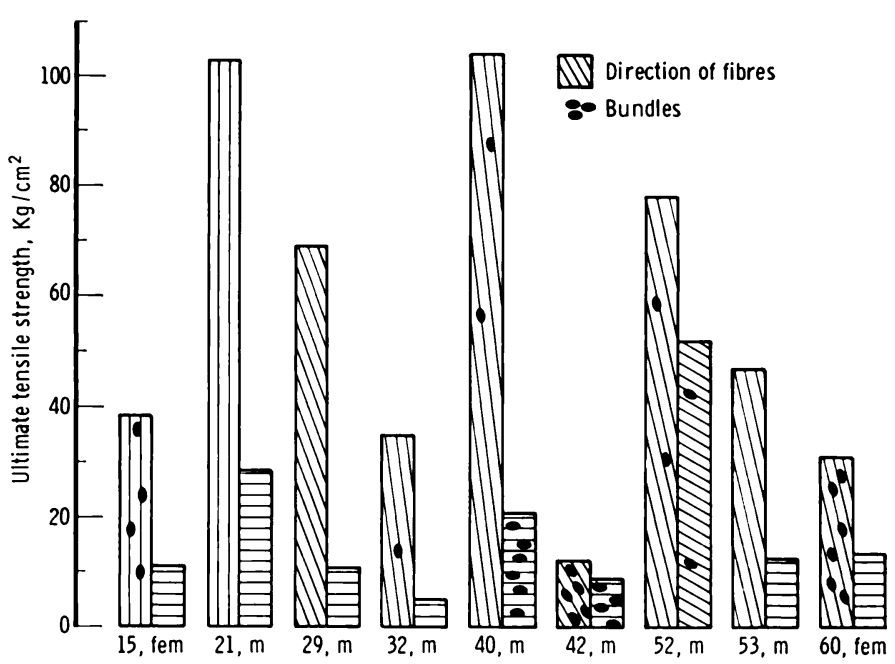

Fig. 10

Bar graph of the ultimate tensile strength of the tissue of the medial meniscus related to the orientation of the collagen fibres in kilograms square centimetre. Each bar represents one specimen with the maximal tensile strength from Table II. The age and sex of the patients from which they were taken are recorded in a manner similar to Figure 9. 
reasonably be expected that adjacent articulating surfaces would have similar load-carrying characteristics.

\section{SUMMARY}

1. The orientation of collagen fibres of the menisci of the knee has been demonstrated by polarised light microscopy.

2. As might be supposed from its fibre structure, the ultimate tensile strength of the meniscal tissue is dependent upon the axis of loading.

3. The tensile strength of the meniscus is similar to that of articular cartilage.

We are indebted to Professor V. Franceschini and Professor C. D'Antonio, both of the Polytechnic Institute of Brooklyn, for helpful discussions and for giving us access to the tensometer used in these experiments. Mr R. Wickiewicz, a second year medical student at Cornell University Medical College, gave valuable technical assistance.

\section{REFERENCES}

Bennett, G. A., WaINe, H., and BAuer, W. (1942): Changes in the Knee Joint at Various Ages with Particular Reference to the Nature and Development of Degenerative Joint Disease. New York: The Commonwealth Fund.

Bullough, P., and Goodfellow, J. (1968): The Significance of the Fine Structure of Articular Cartilage. Journal of Bone and Joint Surgery, 50-B, 852.

Fairbank, T. J. (1948): Knee Joint Changes after Meniscectomy. Journal of Bone and Joint Surgery, 30-B, 664. Goodfellow, J. W., and Bullough, P. G. (1967): The Pattern of Ageing of the Articular Cartilage of the Elbow Joint. Journal of Bone and Joint Surgery, 49-B, 175.

Goodfellow, J. W., and Bullough, P. G. (1968): Studies on Age Changes in the Human Hip Joint. Journal of Bone and Joint Surgery, 50-B, 222.

Kempson, G. E., Freeman, M. A. R., and Swanson, S. A. V. (1968): Tensile Properties of Articular Cartilage. Nature, 220, 1127.

Schubert, M., and Hamerman, D. (1968): A Primer on Connective Tissue Biochemistry. Chap. 8, p. 251. Philadelphia: Lea \& Febiger.

Weinstein, A. M., D’Antonio, C., and Ferraglio, P. L. (1968): The Strength of Thin Vapour Deposited Silver Films. Thin Films, $1,75$. 